“(1) The good must be fully standardized, or capable of standardization; [and] (2) It must be an article of general demand" (Kaldor, 1939, p. 3, emphasis deleted)

\title{
SHADOW BANKING AND THE FINANCIAL SIDE OF FINANCIALIZATION
}

\author{
Eugenio Caverzasi (Università Politecnica delle Marche) \\ Alberto Botta (University of Greenwich) \\ Clara Capelli (CDN Pavia)
}

\begin{abstract}
This paper tries to shed some light on the nature and functioning of shadow banking, with a special focus on its role in the evolution of financialization as well as in sharpening income and wealth inequality. On the one hand, it discusses how securitization has allowed traditional banks to expand their business, providing the financial system with the "raw materials" for the manufacturing of complex structured financial products. On the other hand, it questions the view of traditional and shadow banks as two parallel and alternative systems, claiming that financialization did not alter the role of commercial banks as money creators, but rather diverted endogenously created money to the financial sphere, feeding its expansion. Finally, our work discusses some policy options for the definancialization of the economy through more progressive taxation of the financial sector, as well as a stronger engagement to reduce income and wealth inequality.
\end{abstract}

JEL Codes: E12, E42, E44, E51, G21, G23, G24

\section{Introduction}

Financial and monetary systems have changed significantly over the last decades. Economic theory has struggled to keep up with these changes. Theoretical analysis and economic modelling have often been unable to provide a comprehensive description of the evolution of the financial systems, as well as of 
their implications on the functioning of the economy as a whole.

Since the outbreak of the last financial crisis, studies of the mutation of the financial systems in modern financialized economies have multiplied. Most of them approach the question from a microeconomic perspective and focus on the rationale behind new financial practices, namely securitization; the properties of new financial products and contracts, i.e. collateralised debt obligations (CDOs) and repurchase agreements (repos); the characteristics of relatively new financial institutions such as money market mutual funds (e.g. Coval et al., 2009; Gorton and Metrick, 2010; Adrian and Ashcraft, 2012). Other contributions investigate the role played by such changes in the last financial crisis (see Gorton, 2010; Adrian and Ashcraft, 2010; Gorton and Metrick, 2012) or, more generally, in affecting the stability of the economy (see Tymoigne, 2009). Some papers analyse this last point also by means of formal models (see Eatwell et al., 2008; Nikolaidi, 2015). However, all these works fail to provide a systemic overview of the above-mentioned changes in the financial world, particularly the development of the so-called shadow banking system within the wider phenomenon of financialization.

The literature on growing financialization of modern economic systems is equally abundant and diverse. Some contributions see it as a new accumulation pattern, with finance replacing industry (and manufacturing in particular) as the leading sector where profits accrue (e.g. Krippner, 2005). Other works emphasize the shareholder value orientation of non-financial business activities, according to which non-financial firms increasingly try to raise value for shareholders by retrenching productive investments and increasing their operations on the financial markets (see Lazonick and O'Sullivan, 2000). Signs of financialization are detected in the increasing relevance of financial decisions in everyday life thanks to the "democratization of finance" (van der Zwan, 2014:111): access to financial products and services is no longer a prerogative of the rentiers, but it is also open to low and middleincome households.

These works mostly contribute to define and even gauge the phenomenon of financialization, but largely overlook the financial mechanisms through which it has developed. This paper aims at filling this gap and bridging the two streams of analysis on shadow banking and financialization. Its main 
objective is to capture the role played by the most recent financial institutions and practices in the context of financialization. We first provide a detailed analysis of the functioning of shadow banking to define what kind of financial institutions and practises characterise it. We also discuss the role of shadow banking within the financial system, whether it is solely confined to financial intermediation or also contributes to money creation. Second, we show how shadow banking is a core component of financialization: it has instrumentally allowed financialization to unfold and contemporaneously fuelled some macroeconomic drivers of financialization, such as rising income and wealth inequality.

We draw two sets of conclusions. First, securitization has opened the opportunity for standard banking institutions to expand their business and widen the pool of potential creditworthy borrowers, and - perhaps more relevantly - it has also provided the financial system with the "raw materials", i.e. the securitised assets necessary for the manufacturing of complex structured financial products satisfying the increasing demand for financial assets of financial institutions, seeking either remuneration for intermediated funds, or collaterals for the repo market. Moreover, following Botta et al. (2015), repo contracts, when involving commercial banks as lenders of funds, have contributed to the creation of a credit circuit, largely detached from the real economy and feeding a ballooning and increasingly unstable financial sector.

Second, we claim that (i) the view of traditional and shadow banks as two parallel and alternative systems is ultimately incorrect and potentially misleading. Commercial banks and the different financial institutions generically labelled as Shadow Banks play a separate role in a mutated financial system, which has its cornerstone in securitization; (ii) securitization should be seen as a core element of financialization, since it affects the raison d'être of money creation; (iii) financialization did not alter the special role of commercial banks as money creators, but the special link between endogenous money creation and (non-financial) production can be severely weakened, since money creation may now feed the expansion of finance itself; (iv) while repo contracts increase the liquidity within the financial system, the different kinds of shadow banks interacting with the real sector can only have an intermediation role for the money created by the traditional banking system. 
The purpose of our analysis is not purely descriptive. Any meaningful attempt to de-financialize the economy should start from the understanding of the tight functional link between the financial system and financialization. In this sense, we propose a de-financialization policy strategy based on two pillars. First, following Kregel (2009), a universal banking approach should be adopted to regulate the activities of financial institutions. Second, public authorities should take action against widening income and wealth inequality. As discussed by Botta et al. (2018), the concentration of wealth in the hands of few wealthy rentiers prompted a booming production of remunerative-but-allegedly-safe structured financial products in the runup to the last financial crisis. Any attempt to mitigate or nullify the effects of "unhealthy" finance and rekindle the privileged connection between finance and productive investment must rest firmly within the province and purpose of inequality reduction, which contemporarily feeds and results from financialization.

The paper is structured as follows. Section 2 briefly reviews the existing literature on financialization and discusses how shadow banking is a major building block of financialization. Section 3 describes the main components of the shadow banking system. Our focus is on the US economy, as a paradigm of a highly financialized economy in which most of the innovations associated to shadow banking originated. Section 4 explains how shadow banking is a core component of financialization. Section 5 concludes by discussing some policy options as a possible viable strategy for de-financialization.

\section{A brief literature review about financialization}

Financialization is a rather broad concept, whose recent proliferation has been even criticised for making it too elusive and far-reaching (Christophers, 2015). In one of the first attempts to describe financialization, Epstein (2005) defines it as "the increasing role of financial motives, financial markets, financial actors and financial institutions in the operation of the domestic and international economies (Epstein, 2005:3)", pinpointing the most relevant dimensions investigated by the literature on the topic. 
A first strand of literature conceives financialization as a new accumulation pattern according to which, in the words of Krippner (2005), "profits accrue mainly through financial channels rather than through trade and commodity production" (Krippner, 2005:174). Epstein's financial motives play a pivotal role in driving business decisions. Following van der Zwan, financialization "has empowered those individuals and institutions that derive their incomes from financial assets and transactions" (van der Zwan, 2014:105). Accordingly, due to an increased demand for shareholder return, American manufacturers' "productivity gains have not been reinvested in the corporation, bur rather distributed to shareholders or used for the purchase of financial assets" (van der Zwan, 2014:104). Similar considerations can be found in the literature on the so-called "shareholder value orientation" of firms, which emphasizes the increasing relevance of the maximization of shareholder values in orienting the management's behaviour of US corporations since the 1970s.

Aalbers (2008) discusses the role of financial markets in the domestic economies by introducing the concept of "financialization of home": the possibility for households to get access to mortgages (what Aalbers names "the secondary circuit") increasingly depends on the performance of financial markets on which the mortgages are securitized and sold - in the form of mortgage-backed securities (MBS) - to investors (i.e. Aalbers' "quaternary circuit"). The liquidity characterizing the quaternary circuit enables the expansion of the secondary markets and the rise in the price of housing. Moreover, the development of the MBS market leads "households to see acquiring a house not just as a place to live, but as an investment, as something to put equity into and take equity from". (Aalbers, 2008:152). In the last decades, "home equity affect[ed] what homeowners can spend, how much credit they can get and how they think of the economy at large" (Aalbers, 2008:152). This is a clear example of the fact that "workers and others have become financialized by being drawn into the financial system to meet basic needs" (Lapavitsas and Powell, 2013, p. 375), and, more generally, a vivid image of what the third stream of literature under consideration defines as the "financialization of the everyday". Securitization is often deemed as a crucial step in the development of the so-called "popular finance", i.e. the 
expansion of home equity and the inclusion of previously (financially) discriminated and constrained minorities and ethnic communities into formal financial channels (Dymski, 2010).

It is worth considering two further issues to capture how, according to Epstein's words, financial actors and financial institutions played a leading role in shaping the domestic and the international economy. The first argument is of "political economy" nature. According to Palley (2013), the process of financialization is intrinsically connected with what he calls the "neoliberal box", namely a combination of four economic policies (i.e. globalization, abandonment of full employment, small government and labor market flexibility) at the center of the neoliberal policy agenda shaping government action in the US (but also in other developed countries like the UK) since the late 1970s. The financial sector's call for policies to let financial markets and financial business expand has led the financial sector itself to explicitly promote and support the neoliberal agenda.

The second point regards the dynamics of the economic system as a whole. The real and the financial side of the economy do not develop independently from one another, and thus the evolution of the financial system should be interpreted as the evolution of the whole economy. On the one hand, within the framework of the neoliberal agenda, labor compensation has been decoupled from productivity dynamics, and the wage share has shrunk in favor of capital ${ }^{1}$ (see Palley, 2013:26). Some advanced economies have reacted by allowing the establishment and consolidation of a debt-led economic regime with increasing consumption expenditure fueled by bank credit. On the other hand, such "structural transformation of the relations among non-financial corporations, banks and workers" (Lapavitsas and Powell, 2013:375) has in turn influenced the evolution of the financial system, and the emergence of shadow banking. In his theory of the financial stages of US capitalism, Hyman Minsky (1988, 1996) described how each stage features different financial and industrial structures and a specific relationship between the financial and the real sector. The last one, Money Manager Capitalism (MMC), has been interpreted as largely overlapping with the concept of financialization (e.g. Zalewski and Whalen, 2010). MMC is primarily characterized by the rise of financial funds, holding a large portion of the liabilities issued by corporations hence influencing their management, and is consistent 
with Epstein's stand on financialization. Second, there exists a "symbiotic relation between the growth of securitization" (Minsky,1988:36) and this new form of capitalism, as under securitization it is possible to build the assets that exactly meet the specific needs of different investment funds.

Christophers (2015) argues that "financialization is typically depicted as something that is done by finance to or within other or wider domains: life, business, and capitalism [...] yet finance itself - its institutions, its functions, its revenue-and-profit-generation models - is all too often black boxed" (Christophers, 2015:191). Minsky's view on the US financial system partially rebuts this critique, but we want to further stress how shadow banking and the related practices have reshaped finance and redirected banks' business models from standard credit creation for productive activities to open market operations (e.g. the production and sale of structured financial products). We will also show how securitization represents the major financial innovation enabling banks to expand credit provision to households (rather than productive firms) and make financialization amongst the middle and lower classes possible.

\section{Shadow banking and the evolution of the US financial system}

Interest in shadow banking has soared after the sub-prime crisis due to the role played by shadow banking institutions (e.g. Brokers and Dealers and Money Market Mutual Funds) and practices (e.g. mortgage securitization, repo lending, and the production of structured financial products such as CDOs) in the generation or propagation of the crisis.

However, an agreed definition is yet to be found (Claessens et al., 2012). Paul McCulley, former Managing Director at PIMCO investment fund, is generally considered as the father of the expression "shadow banks". He referred to those financial intermediaries lending money and funding their banking activity bypassing standard regulation, and “without backstopping from the Federal Reserve's discount lending window or access to FDIC deposit insurance" (McCulley, 2009:1). In a similar vein, Gorton (2010) and Gorton and Metrick (2010), Pozsar et al. (2013) describe shadow banking as an alternative depository system based on collateral rather than public insurance. Consistently with this 
perspective, Gorton and Metrick (2012) prefer to switch to the term securitized banking, in order to emphasize how the securitizing, warehousing and packaging of loans (especially mortgages) was intended to provide the system with new safe securities, together with credit default swaps issued by private insurance companies, as collaterals of loans and hence private guarantees other than official insurance and FED's discount window.

All the aforementioned contributions see shadow banking as a system of lending institutions performing functions traditionally attributed to regulated depository banks, but operating outside the regulatory framework of monetary authorities. This view is however not undisputed. Fein (2013), for instance, claims that shadow banks "exist as an integral part of the regulated banking system" (Fein, 2013:2), and most of the practices usually considered as shadow banking actually originate, are performed, or are at least indirectly related to traditional regulated financial operators.

Despite the definitional dispute, two common elements can be highlighted: (i) the central role of securitization in shadow banking; (ii) the idea of securitization as a form of credit intermediation alternative to traditional (commercial) banks ${ }^{2}$. While agreeing on (i), we reckon that (ii) is misleading and provide some arguments in support of our thesis.

\subsection{Shadow banks versus commercial banks: a preliminary theoretical clarification}

The term shadow banking implicitly assumes that traditional (commercial) banks and shadow banks are two parallel and alternative systems performing analogous functions and acting as pure financial intermediaries, as theorized by Ricardo, the currency school and Friedman's monetarism. The development of New Consensus models did not help clarify this point, since endogenous money supply was treated as the result of policy choice rather than of the intrinsic dynamics of money creation.

A clearer distinction between banking activity (e.g. depository banks) and the business of "money lender came with the post-Keynesian endogenous money theory. According to Minsky, "banking is not money lending; to lend, a money lender must have money. The fundamental banking activity is 
accepting to guarantee that some party is creditworthy. A bank, by accepting a debt instrument, agrees to make specified payments if the debtor will not or cannot". In doing this, "[a banker] needs not have uncommitted funds at hand" (Minsky, 1986:256). Indeed, "the lending function of a commercial bank $[\ldots]$ consists in the practice of extending loans far in excess of either the capital or cash holdings of the bank in question" (Kregel, 2016:7). Accordingly, "money is an endogenously determined variable - the supply is responsive to the demand and not something mechanically controlled by the Federal Reserve [...] money, as bank liabilities, emerges out of the processes by which investment and positions in the stock of capital assets are financed" (Minsky, 1986: 252 - 253, italics added).

In post-Keynesian monetary theory, the economic system endogenously creates money ex nibilo through commercial banks issuing credit on demand to creditworthy borrowers. Deposits are created by banks through loans with no prior needs for funds nor reserves, as central banks accommodate banks' needs for reserves. The causality is reversed with respect to the standard money multiplier narrative. Furthermore, the credit-based money creation theory characterising post-Keynesian economics establishes a tight relation between money/credit creation and firms' production (see Lavoie, 1984; Rochon, 1999; Parguez and Seccareccia, 2000). Commercial banks can create ’proper money' (i.e. banks' deposits are at the centre of the payment system and unanimously accepted to clear debts) due to their special relation with central banks (Rochon and Rossi, 2007; Gabor and Vestergaard, 2016) ${ }^{3}$, thanks to which banks' deposits are implicitly based on reserves, namely central bank money. Consequently, commercial banks, unlike other financial institutions, can act as intermediate institutions between monetary authorities and the economic system. The money they create to the benefit of the latter then allows for production to take place, and income to be generated, by bridging the time gap between production costs (say wage) and firms' revenues.

The peculiar role that commercial banks play in a monetary production economy within the postKeynesian theoretical framework is crucial for two reasons. First, it is important to understand how this role has changed as a consequence of the development of shadow banking, and in light of the relation between commercial banks and shadow banks. By deciding how much credit is issued ex nibilo and to 
whom (productive firms or shadow banks), commercial banks can determine the path of an economy and its stability; if credit creation is misdirected, for instance by inflating bubbles or financing unstable positions, this leads to higher financial fragility (Minsky 1986:279). Second, this approach clarifies the difference between "bank money" and "shadow money", which, according to Gabor and Vestergaard (2016), is implied by the existence of shadow banks. In the economy, "there is a hierarchy of monies, with special money instruments for different purposes [...] everyone can create money; the problem is to get it accepted" (Minsky, 1986:255).

\subsection{Transformation in the US financial system}

The existing literature on financialization lacks an exhaustive analysis of the changes the financial system went through over the past four decades (Christophers, 2015). We will try to fill this gap in the present section. We will focus on the US economy and provide an overview of the metamorphosis of the US financial system based on the aggregate balance sheets of its main institutions. Figure 1 shows the relative size of each sector of the US financial system from 1975 to $2017^{4}$.

[Figure 1]

The size of the traditional banking sector (i.e. Private Depository Institutions) has decreased from more than $40 \%$ to approximately $20 \%$ of the whole financial system in terms of assets value. This dynamics is mirrored by the growth of investment funds, which became the largest sector in 2013 . The other key feature is the emergence of three sectors that were either absent or marginal in the 1970s: Security Brokers and Dealers, Issuers of Asset Backed Securities, and Money Market Mutual Funds. Right before 2008 , they jointly accounted for almost $20 \%$ of all the assets in the US financial sector.

\subsubsection{Commercial Banks}

In Figure 2, Panel 2A shows the assets held by depository institutions. Together with commercial 
(chartered) banks, which represent by far the largest component, this sector includes saving banks, cooperative banks, and lending institutions.

\section{[Figure 2]}

The key features of this sector are: (i) the weight of mortgages, which account for the largest asset peaking to about $40 \%$ right before the 2008 crisis; (ii) the relevance of Agency and Government Sponsored Enterprises (henceforth GSEs) backed securities, that more than doubled their relative size between the 1970s and the mid-1990s; (iii) the fall in the relative size of other loans, such as commercial and industrial loans. These data are the result of a very long and complex evolution of the banking sector. In a nutshell (see Kregel, 2009), the development of financial markets offered new financing instruments to firms (e.g. commercial papers), while traditional banks shifted from financing short-term business needs to longer-term households' debt. Interest rate hikes, competition for retail deposits from thrifts and the attempt to circumvent regulations pushed banks to create new financial products and expand their trading activity. As a consequence of financial deregulation and the dismantling of the Glass-Steagall Act, commercial banks moved from the traditional originate to hold model of lending - in which profitability was guaranteed by their ability to assess the creditworthiness of the borrowers - to an originate to distribute model, with profits originating from fees, commissions, and trading of securities.

\subsubsection{Asset Backed Security Issuers}

Asset Backed Security Issuers or Special Purpose Vehicles (SPVs henceforth) were not included in the US Flow of Funds until 1981 It refers to mortgages, mortgage-related assets (GSE securities) or other types of loans (e.g. car and student loans, credit card receivables, home equity loans) that are given by traditional banks and subsequently entered into the securitization process.

SPVs are specialized financial institutions with a simple balance sheet structure, low capital and minimal organization structure. They are the main 'securitizing sector', since they lie between the 
original creator and supplier of their assets, i.e. the banks, and the non-banking financial system. SPVs finance the purchase of securitized assets by issuing bonds and commercial papers, often purchased in turn by the sponsoring institutions (the bank that created the SPV). SPVs then produce and sell assetbacked securities to other non-bank financial institutions. In so doing, they repay their original debt and allow for payments and interest flows to be distributed through the system. Such asset-backed securities become the input used by other financial actors (Brokers and Dealers) for the production of structured financial products. The steep rise and the rapid fall in the relative size of this sector with respect to the GDP and its growth relative to the whole financial system are shown in Panel 2D. Such dynamics should not come as a surprise given their specialization and their centrality in the securitization process.

\subsubsection{Money Market Mutual Funds}

MMMFs are the second "new financial sector" in our stylized facts. They appeared in the 1970s and quickly expanded as a better option for cash-rich investors (including investment funds) with respect to standard banks' deposits. First, depository institutions' regulation (Regulation Q) usually impose a cap to the interest rate paid by standard depository institutions on deposits. Second, banks' deposits are protected by the FDIC guarantee up to a certain limit. This fact represents per se a competitive advantage for MMMFs. They can offer a higher remuneration on largely liquid assets, (mainly) uncovered by the FDIC insurance, since they do not have to pay any insurance premium to FDIC. Thirdly, MMMFs' shares were perceived as an equally safe form of investment as banks' deposits. This belief was grounded to a certain extent on the regulatory limits requiring MMMFs to invest only in highly rated assets, and on the implicit public protection provided by public institutions (Pozsar et al. 2013:4). This conviction was indeed confirmed during the crisis, as MMMFs were largely bailed out by the government (Olson, 2012).

MMMFs significantly increased their relative size with respect to the GDP, as well as to the whole financial system (see Figure 2F), by attracting funds from cash-rich investors and big corporations (e.g. Bates et al. 2009). The composition of MMMFs' assets (Panel 2E) has changed significantly since the 
1970s. Initially, it almost exclusively consisted of three assets, namely Treasury securities, deposits, and short-term open market papers. Along with corporate bonds, asset-backed securities and repos have been core assets in MMMFs' portfolios since the 1980s. This shows how MMMFs' core business is strictly related to securitization. Repos are the key form of credit between financial institutions and are used by MMMFs as collateralized lending to provide liquidity to the financial sector.

All these assets, as well as other securities backed by the public sector (such as GSE securities), were considered to be very safe before 2007. When the crisis unfolded, ABS and GSE-backed securities were severely hit due to GSEs' exposure in the mortgage-related security market. Many doubts arose about the ability of MMMFs to maintain the value of their shares equal to one dollar, the crisis escalated and MMMFs fire-sold their assets in order to satisfy mounting redemption requests. The intervention of the US government to backstop MMMFs through the MMMF Temporary Guarantee Program eventually proved that MMMFs were actually backed by public guarantee as it had always been implicitly expected.

\subsubsection{Brokers and Dealers}

The third main sector is Broker and Dealers (or Investment Banks). Figure 2H shows that its weight has considerably increased with respect to the whole financial sector and to the GDP until the outbreak of the crisis.

The aggregate balance sheet of Broker and Dealers (Figures $2 \mathrm{G}$ and $2 \mathrm{H}$ ) shows how repos are a key element on both the asset and liability side. Figure $2 \mathrm{H}$ in particular shows the central role that Investment Banks had in the repo business in the eve of crisis. The sector as a whole is a net borrower, with commercial banks as major providers of cash (Copeland et al. 2012. $)^{5}$. The balance sheet of investment banks is composed of short-term liabilities used to finance long-term assets (Pozsar et al., 2013). This inevitably exposes investment banks to the risks associated with liquidity mismatches. Repos, considered a trustworthy form of "insured" loan as collateralized by long-term (safe) asset, appear as an ideal solution to such misalliance. They became the major source of funds for this system 
and gradually replaced "uninsured" bank loans. The development of the repo market also created significant arbitrage opportunities for investment banks acting as primary dealers. Primary dealers own large stocks of safe assets to perform their role of intermediaries of FED funds in the monetary market and gain positive rate differentials. Investment banks borrow from banks with safe collateral (e.g. Tbills), which is cheap, and lend to borrowers who hold less safe collateral (e.g. ABS), which is more expensive (see Adrian et al. 2013). This explains the limited role of liquidity in the form of 'deposits and currency' within investment banks. Repos, rather than deposits, are Brokers and Dealers' liquid assets. Investment banks are at the heart of the US monetary system. On the one hand, they are the largest actors in the repo market and intermediaries of FED funds. On the other hand, "they originate new securities and produce derivatives" (Adrian and Shin, 2010:5, italic added).

\subsubsection{Securitization: Alchemic finance?}

Securitization is arguably the major novelty of the US financial system in the last decades (Gorton and Metrick, 2012). It is the transformation of banks' credit assets into securities, which are then sold in the financial market. Table 1 describes a stylized securitization process of four steps encompassing the four sectors described above. In each step (T1, T2, T3, and T4), entries in the social accounting matrix with signs represent flows, whilst the entries without a sign are not to be considered in that specific step, but may help follow ${ }^{6}$.

T1 represents the standard process of endogenous money creation. Money in the form of deposits is created ex nibilo through loans, mortgages in our example. In T2, credits - mainly mortgages (M) issued by banks are sold to SPVs in exchange for deposits. At the micro level, these deposits are credited to an account that the securitizing bank maintains with another bank. At the aggregate level, this leads to a reduction of deposits, which were an asset for SPVs and a liability for the banking sector. SPVs finance the purchase of assets from commercial banks by issuing corporate bonds and commercial papers. Such liabilities will eventually be repaid through the revenues accruing to SPVs by selling ABS to other financial institutions. This occurs in T3. SPVs gather purchased assets into pools 
and partition them into tranches, usually senior, mezzanine, and junior, with an increasing level of risk. The tranches are then sold as ABS to other financial institutions according to their risk preferences.

Before the crisis, investment banks purchased large amount of ABSs, issuing liabilities to commercial banks and MMMFs, through repos. At T4, investment banks use ABS to produce complex structured financial products such as Collateralized Debt Obligations or CDOs squared $\left(\mathrm{CDO}^{2} \mathrm{~s}\right)$. As a combination of assets with a supposedly low-risk correlation, these products obtained very high ratings (often triple-A), even when the underlying assets were highly risky, as in the case of sub-prime mortgages. They were perceived as relatively remunerative-but-safe financial assets. Accordingly, they were mostly purchased by MMMFs, hedge, investment, and pension funds, since they appeared to be perfectly consistent with the aim of "achieving the maximum return for beneficiaries with minimal risk (D'Arista, 1994: 264)" guiding the behavior of such institutional investors ${ }^{7}$. Securitization prompted a process of "alchemic" transformation of financial assets from commercial banks' loans into "composite" securities mainly aimed at satisfying the appetite for remuneration of institutional investors. Following Toporowski (2000), and Nersisyan and Wray (2010), the astonishing development of such a battery of securitized assets stands out as clear evidence of the destabilizing role played by private-based pension schemes and huge pension funds (Minsky's money market managers, more generally) on the performance of financial markets, as well as of the progressive departure of capital markets from their core function of financing long-term capital formation, as early noted by D'Arista (1994).

\section{[Table 1]}

\subsubsection{Repos in the financial and in the monetary system}

One of the key features of the shadow banking system is the widespread use of repos as a source of funds. According to Gorton and Metrick "[s]ecuritized banking is the business of packaging and reselling loans, with repo agreements as the main source of funds.” (Gorton and Metrick, 2012: 425). 
Repos are a peculiar form of collateralized lending, in which the possession of the collateral - usually a security - is passed to the borrower for the duration of the loan. In repo contracts, the borrower commits to repurchase the collateral at a given time and at given price, the difference between the selling price and the repurchase price being the related interest rate.

Repos are short-term instruments. A special kind of repo agreements, open repos, automatically renews until the decision of at least one party. They are also considered as very safe forms of lending. First, repo contracts are exempt from bankruptcy claims. For the duration of the agreement, the lender is entitled to the full property of the collateral if the borrower goes bankrupt. Second, the value of the collateral exceeds that of the money borrowed (this difference being the so-called haircut), unless it falls in the meantime. Third, the assets used as collaterals are standardized and usually seen as safe securities. Different classes of assets are used in different kinds of repos. Treasury securities, for instance, are required to borrow reserves and are considered as the safest assets in the system with the lowest haircut.

These properties raise confidence in repo contracts, making them very liquid assets. Since the 1980s, repos became so popular that they largely replaced bank deposits as the main liquid assets in the money market. The demand for high-rating collaterals of repo contracts increased so much that financial institutions started to produce and supply them (i.e. ABSs and CDOs). Different studies estimated that the size of the repo market hit about 10 trillion dollars before the sub-prime crisis (e.g. Baklanova et al. 2015, Gorton and Metrick 2012). Confidence is obviously crucial, and Gorton and Metrick (2012) aptly stress how the sub-prime crisis became a systemic crisis following a general loss of confidence in the value of repo collaterals, which in turn gave rise to a run on repos and a sudden dry of liquidity in the entire system. After the outbreak of the crisis, the size of the repo market plunged to about 5 trillion dollars. 


\section{Shadow banking and the financial dimension of financialization.}

\subsection{Financial commodification and the financial side of financialization}

The transformations undergone by the US financial system can be seen as the main drivers of financialization over the past decades. In particular, we believe that the development of shadow banking has played a major role in shaping the whole process of financialization and, more specifically, what we call "the financial side of financialization".

Securitization lies at the heart of such evolution. Its ultimate goal is to give rise to a much "more rapid circulation [of capital] relative to production" (Lapavitsas and Powell, 2013: 363) and can be better understood as articulated along three stages: (i) credit creation; (ii) commodification of credit positions; and (iii) production of financial assets. All of them are intrinsically interconnected with the repo market.

As regards the commodification of credit in the securitizing system, banks' (securitized) loans lead to money creation - in the form of deposits - but also satisfy the demand for standardized loans to be transformed into complex financial assets by investment banks. Bank loans can thus be deemed as financial raw materials. They are primarily the inputs for the "manufacturing" of advanced financial products (ABS, CDOs, $\mathrm{CDO}^{2}$ s etc...etc). Following Lysandrou (2005), securitization gives rise to the 'commodification of credit position'. This originated from Marx's view of capital as a commodity (Marx, 1981:468) ${ }^{8}$, but also fits standard definitions of a commodity as "a Standardized good which is traded in bulk and whose units are interchangeable" (Black, 2003: 66).

As for the production of financial assets, investment banks may be better understood as financial firms rather than 'shadow banks' or financial intermediaries. Following Adrian and Shin (2010:5), investment banks "are at the heart of market-based financial systems", and their core business increasingly consists in the trading and production of financial goods, from the most liquid (deposits and repos) to longer-term ones (securities). First, the time horizon of such production activity may be extremely short. The collection of liquidity through repos, the purchase of financial commodities, the 
production of derivatives, the sale of these financial products, and the repayment of the repos can all take place in a single day. Second, the production activity of investment banks heavily depends upon traditional banks, from which they receive finance and, at the same time, buy financial inputs. Credit from commercial banks to investment banks through repos allows for a "financial circuit" to take place, the manufacturing of financial products being its final outcome (Botta et al., 2015). Consistently with traditional post-Keynesian monetary theory, credit and production are still intimately connected. From this approach, it is possible to reappraise - at least partially - the relationship between money creation and production that Michell (2016) considers to go lost in the shadow banking system, while contemporarily shifting the focus from the real side of the production of tangible goods and services to the realm of finance and of the production of financial products.

As mentioned above, these stages are deeply connected with the repo market. The overgrowth of the financial industry relative to the rest of the economy is not merely the result of capital seeking for remuneration in the financial sphere. It is also due to an independent evolution of the financial system, which became an "autonomous sphere for capital accumulation with its own independent logic (Christopherson et al., 2013: 353)"'. Such independent accumulation process within the financial sector, which we may conceive as an advanced example of alternative finance-based accumulation regime, is rooted in the production of new financial products via securitization and their subsequent circulation via repos. More specifically, there seems to exist a hierarchy of securities mirroring the well-known hierarchy of money (Bell, 2001; Mehrling, 2012). Higher-ranked securities pledged as collateral in repo contracts give access to cheaper liquidity. Securities of the highest quality, Treasury bonds for instance, give access to FED's reserves, and are also used in the GCF repo market at slightly higher repo rates and haircuts. Newly produced AAA-ranked securities such as MBS or CDOs, in turn, have fuelled the rapid expansion of more expensive but still relatively convenient repo contracts. Together with the extreme velocity of this market, these assets have opened a large space for arbitrage among different repo contracts, and new profits opportunities for financial institutions (Baklanova et al. 2015. See also Section 3.2.7). Repo markets have represented an additional source of manufactured asset-backed 
securities next to the standard demand of rentiers, financial funds and financialized non-financial corporations.

Securitization expands because of its capacity to meet the needs of different economic sectors. Following Botta et al. (2018), securitization has allowed commercial banks to ameliorate their balance sheets while bypassing capital requirements, expand their business, reach out to new customers (i.e. households in need of a mortgage or financial institutions involved in the securitization process) and, ultimately, increase their fee income. Securitization has provided investment banks with the necessary inputs for the production of new financial instruments to be sold in the financial market and used as collaterals for their repo financing and arbitrage activities. Finally, securitization has enabled financial firms to produce customized assets based on the specific needs of MMMFs or any other type of investment funds.

The real side of the economy enjoyed some immediate benefits too. First, the household sector benefited from an easier access to loans, i.e. the abovementioned democratization of finance or "financialization of the everyday". Second, (financialized) non-financial firms reaped the relatively high returns guaranteed by manufactured structured financial products in which they invested through the intermediation of MMMFs and other institutional investment funds. Shadow banking created the conditions for the production of the financial products that shareholder-value-oriented managers of non-financial corporations were seeking.

Whilst everyone seemed to benefit from shadow banking-related activities at the micro or sectorial level, the overall system went through major drawbacks and became increasingly fragile. Shadow banking-related alchemic finance appeared to be an illusion, once again all that glitters is not gold.

\subsection{The destabilising effects of shadow banking}

Following Botta et al. (2015), this process shows a self-feeding dynamics, since banks play a double role. They both determine the supply of the financial commodity and finance its demand, funding the securitizing system through repos. Such dynamics is very likely to go hand in hand with instability. 
The reason is twofold. First, securitization may be viewed as a macro-paradox ${ }^{8}$ related to the fallacy of composition. Before the sub-prime crisis, securitization and the production of structured financial products was believed to improve the stability of the system. On the one hand, securitization contributed to fragment and distribute small portions of risky assets diluted amid several assets and packed into apparently much safer complex multi-collateralised financial products (i.e. CDOs). On the other hand, it facilitated commercial banks and other financial institutions to individually improve their leverage, while potentially increasing their profitability (see Botta et al. 2018). What seemed negligible if not remunerative - at the micro level, became disruptive at the macro level. Commercial banks could hardly identify creditworthy borrowers, as they did not bear the risk of the loans once they have been securitised: when these practices became consuetudinary, the reduction of the financial risk at the micro level coupled with an increasing systemic risk ${ }^{10}$. Because of the opaque structure of these financial products, it was almost impossible to distinguish between safe and unsafe assets. This led to a major loss of confidence in the system, and consequently to the collapse of the market (Gorton and Metrick, 2012). This is in line with Minsky's Financial Instability Hypothesis (Minsky, 1975), although the risk-increasing behaviour is not due to the exuberant "animal spirits" of the real sector, but rather to a deliberate (and legal) manipulation of the balance sheets.

Second, access to liquidity through repo financing is intrinsically unstable, as it heavily relies upon the liquidity and valuation of the underlying collaterals. If the liquidity providers are concerned about the real value of repo collaterals, then repo rates and haircuts will suddenly increase, and liquidity dry up. This could even worsen if borrowers and lenders jointly fire sell assets and collaterals in the attempt of making up for the losses in defaulting loans, returning to "proper money", or satisfying requests of redemption. More than ten years after the crisis, it now seems clear that shadow banking mechanisms based on repo financing are highly pro-cyclical and are affected by a "radical form of uncertainty (that) does not apply in the same way for other money claims (Gabor and Vestergaard, 2016: 25)".

A third factor of finance-led systemic instability refers to how shadow banking contributed to generate the housing bubble. Most of the works on the causes of the US housing bubble focused on 
factors related to the real economy, international macroeconomic disequilibria (Bernanke et al., 2011), or mistakes in monetary and/or fiscal policy (Taylor, 2009). Yet, they tend to overlook the other side of banks' balance sheets, and ignore the possibility that the housing bubble might have been the result of a boom in the demand for complex financial products in the context of the shadow banking system. Through this lens, the housing bubble could be conceptualized as a financial commodity boom similar to those in (real) commodities (Canuto, 2014; Erten and Ocampo, 2013).

Botta, Caverzasi and Tori (2018) and Botta et al. (2018) analyse the distributive properties of growth regimes governed by the development of shadow banking. In line with Argitis and Pitelis (2001) ${ }^{11}$, they show how shadow banking is instrumental to the creation of a rentier-friendly economy in which income is redistributed from working households to rentiers, so that income and wealth inequality increase even in a context of booming economy. The concentration of wealth and the financialization of non-financial firms in turn fed and stimulated even further the secular rise in the demand for remunerative financial assets as put forward and intermediated by the (long-run) development of different types of investment funds and MMMFs. Together with the increasing quest for collaterals in the repo market, all these factors stimulated - from the demand side - securitization and investment banks' production of CDOs, ABS and MBS. The ultimate precondition for larger manufacturing and higher supply of these financial products is the vigorous expansion of mortgages, which in turn can destabilize the housing market. The sharp upswing in ABS and mortgages, as shown in Figures $2 \mathrm{~B}$ and 2D. empirically supports our view.

The housing market seems to be particularly affected by these demand-side forces. Mortgages are in fact ideal financial assets for securitization, because they are backed by a real asset (dwellings) with a long-lasting and apparently robust price. Mortgages are also quite easy to score and standardize. The production of securitized assets is obviously not limited to mortgages only, but encompasses a much wider set of loans (Botta et al. 2018). Following Mayer (1998:208), "we should accept the idea that in the future anything that can be securitized will be securitized". 


\subsection{The financial side of financialization and its implications for monetary theory}

In 1963 Tobin refuted the endogenous money theory claiming that commercial banks cannot limitlessly stretch credit, due to restrictions imposed by regulatory capital requirements. Yet, our analysis shows that securitization has contributed to significantly loosen bank's balance sheet constraints and can even trigger off a self-feeding process of expansion. Considering banks just as financial intermediaries, as most of the literature on shadow banking still does, is not only inappropriate, but also dangerous for policy-making. The major distortions that securitization generated in the housing market through endogenous money creation are still bound to exert their destabilizing effects, perhaps in other markets. This will translate into bubbles and other major disruptions in the real sector, unavoidable "side effects" of these financial practices.

The label "shadow banks" is ultimately incorrect and can hardly effectively inform policy-making. The financial sectors we analysed are often complementary and not alternative to standard banking activity. For instance, the difference between MMMFs and commercial banks does not just depend on the nature of the underlying guarantees - private vs public - of their liabilities. In their relationship with the real side of the economy, MMMFs do not create credit (or bank) money ex nibilo, but rather follow the rules of financial intermediation: they need a stock of savings (or savers willing to purchase their liabilities) in order to lend and transfer funds by buying securities (mostly backed by some assets). Conversely, their liabilities, albeit highly liquid, cannot be used for final payments nor for debt settlement and therefore lie at a lower level in the money hierarchy with respect to bank money (Gabor and Vestergaard, 2016). MMMFs themselves need to rely on banks' deposits (and not central bank money) in order to open new or close existing financial positions. MMMFs rather seem extremely liquid versions of investment funds than a shady version of commercial banks. They may compete with banks in providing savers with access to a very liquid asset, but not in being the primary "creators" of finance ${ }^{12}$.

Even the other financial sectors taken into consideration fail to show a neat parallelism with commercial banks. Gabor and Vestergaard (2016) consider repos as a new form of money since they 
can (hopefully) be liquidated at par by selling the underlying collateral in case of need (i.e. the bankruptcy of the borrower). We disagree with this perspective. Repos are certainly very liquid shortterm assets. Nevertheless, they are not perfect substitutes for deposits, as they cannot be used for final payments. Their liquidity strongly depends on the perceived degree of safety characterising the underlying collateral, not from any special relation with the central bank (which is why the market for repo contracts using MBS or CDOs as collaterals suddenly dried up after the outbreak of the crisis). High velocity in the repo system (Singh, 2011) allows a growing volume of financial transactions from a given amount of deposits, but does not increase the quantity of money created into the system.

We agree with Michell (2016:8) when he claims that commercial banks are still necessary as a final means of settlement, and both MMMFs and investment banks still need banks money - directly or indirectly - for their operations. Repos can certainly increase the liquidity and the leverage of the financial system. However, the liabilities they create can only represent a fictitious form of liquidity (Nersisyan and Dantas, 2018), which fuels the internal dynamics of the financial system but cannot be used for debt settlement neither in the real and nor in the financial side of the economy.

Financial deregulation has undoubtedly made the difference between financial institutions merely fictional, but the specific role of commercial banks as money creators and as well as the link between the real, financial and monetary spheres still holds valid. This has significant policy implications at the institutional level, with the ultimate aim to tame the disruptive systemic effects of the financial side of financialization and pave the way towards the "de-financialization of finance", in order to reclaim the original and primary role of the financial sector of attending the needs of the real economy.

\section{Towards the de-financialization of the economy: some concluding remarks}

In this paper we analyzed the major transformations of the US financial system over the last decades. We argued that the development of the shadow banking is perhaps the most relevant phenomenon, although it is still largely unexplored. Shadow banking emerges as the "the financial side of financialization", prompting the course of the process of financialization of the economy. 
We showed how securitization has led to the "financialization of the everyday" by allowing for the extension of credit to a much larger audience. Such expansion in bank credit was not intended to address the needs of common people, but was rather driven by the increasing demand for financial commodities to be used in the manufacturing of complex financial products remunerating financial investments done by wealthy rentiers and financialized non-financial firms. More generally, we argued that shadow-banking practices have contributed to the development of an advanced form of financecentered accumulation regime, in which capital accumulation increasingly depend on self-generated profit opportunities within the financial sector.

Shadow banking also had an impact on the real economy, mainly a destabilizing one. Securitization, for instance, boosted the capacity and willingness of banks to create credit, which in turn led to the housing bubble and the sub-prime mortgage crisis. Shadow banking has also increased wealth and income inequality in the most advanced economies since the beginning of the 1980s. Kumhof et al. (2015) and Botta et al. (2018) show how increasing income and wealth inequality fueled even further the secular rising demand from institutional investors and pension funds for remunerative and apparently safe (but eventually obscure) assets produced by the shadow banking system.

Public authorities should first take action in this domain. Fiscal authorities, for instance, should implement a more progressive taxation scheme, particularly targeting capital income and accumulated wealth; they may also subsidize via fiscal incentives firms' decisions to re-invest profits in $\mathrm{R} \& \mathrm{D}$ or other production and productivity-enhancing activities, whilst discouraging financial capital accumulation.

Second, public authorities must engage in the de-financialization of finance through effective regulation of the financial system grounded on an insightful understanding of the financial system itself, and of the rationale of the different financial activities. Financial regulators, for instance, might impose restrictions on the portfolio composition of any financial institution that "creates bank money" and has a privileged access to the desks of the FED. For instance, such institutions might be tightly restricted from providing credit to other financial institutions via repo. Treasury securities should also be 
classified as the exclusive assets eligible as collaterals in repo contracts to discourage the manufacturing of complex financial products that may eventually feed an uncontrolled and unstable expansion of the repo market ${ }^{13}$. Ultimately, following Lavoie (2012), regulatory institutions should impose the return of securitization to its original forms. Financial institutions awarding mortgages could be allowed to issue MBS as a form of liability management that may help collect funds at relatively cheap interest rates. However, both mortgages and related MBS will have to remain on their own balance sheets, instead of moving onto the balance sheet of elusive SPVs. This will crack down on regulatory arbitrage and restore financial institutions' engagement in the screening and monitoring of borrowers' creditworthiness.

Such binding financial regulation is likely to significantly reduce liquidity in the financial system, as higher liquidity is not a virtue in itself, particularly when it is fictitious liquidity mainly instrumental to financial speculation. Privatized Keynesianism has sharpened instability rather than taming it. Accordingly, it should be replaced by a new form of public Keynesianism, in which public housing and better "social infrastructures" are financed through progressive taxation of income and wealth, what we consider the first action to be taken towards de-financialization. 


\section{References}

Aalbers, M.A. 2008. The financialization of home and the mortgage market crisis, Competition and Change, vol. 12, no. 2, $148-166$.

Adrian, T. and Ashcraft, A.B. 2010. The changing nature of financial intermediation and the financial crisis of 2007-09. Federal Reserve Banks of New York Staff Reports no. 439.

Adrian, T. and Ashcraft, A.B. 2012. Shadow banking: A review of the literature, Federal Reserve Bank of New York Staff Reports no. 580.

Adrian, T. and Shin, H.S. 2010. Liquidy and leverage, Journal of Financial Intermediation, vol. 19, no. 3, 418-437.

Adrian,T., Begalle, B. Copeland, A. and Martin, A. 2013. Repo and securities lending, Federal Reserve Bank of New York Staff Reports no. 529, December 2011; revised February 2013

Baklanova, V, Copeland, A., and McCaughrin, R. 2015. Reference guide to US repo and securities lending markets, Federal Reserve Bank of New York Staff Reports no. 740.

Bates, T.W., Kahle, K.M. and Stulz R.M. 2009. Why do US firms hold so much more cash than they used to? The Journal Of Finance, vol. 64, no. 5, 1985-2021.

Bell, S. 2001. The role of the state and the hierarchy of money, Cambridge Journal of Economics, vol. 25, no. $25,149-163$.

Bernanke, B.S., Bertaut, C. DeMarco, L.P., and Kamin, S. 2011. International capital flows and the returns to safe assets in the united states, 2003-2007, Board of Governors of the Federal Reserve System International Finance Discussion Papers no. 1014.

Black, J. 2003, Oxford dictionary of economics. Oxford University Press.

Botta, A., Caverzasi, E., and Tori, D. 2015. Financial-read side interactions in an extended monetary circuit with shadow banking: loving or dangerous hugs?, International Journal of Political Economy, vol. 44, no. 3, 196-227.

Botta, A., Caverzasi, E., Tori, D. 2018. The macroeconomics of shadow banking, Macroeconomic Dynamics, doi: 10.1017/S136510051800041X. 
Botta, A., Caverzasi, E., Russo, A., Gallegati, M., Stiglitz, J.E. 2018. Inequality and finance in a rent economy, Greenwich papers in political Economy no. 66.

Christophers, B., (2015). The limits to financialization, Dialogues in human geography, vol. 5, no. 2, 183 200.

Canuto, O. 2014. The commodity super cycle: is this time different?, Poverty Reduction and Economic Management (Prem) Network. World Bank, June 2014, no. 150.

Christopherson, S., Martin, R., Pollard, J. 2013. Financialization: roots and repercussions, Cambridge Journal of Regions, Economy and Society, vol. 6, no. 3, 351 - 357.

Claessens, S., Pozsar, Z, Ratnovski, L. and Singh, M. 2012. Shadow banking: economics and policy, IMF Staff Discussion Note no. 12/12.

Copeland, A. Duffie, D., Martin, A. and McLaughlin, S. 2012. Key mechanics of the US tri-party repo market, FRBNY Economic Policy Review, vol. 18, no. 3, 17 - 28.

Coval, J. Jurek, J. and Stafford, E. 2009. The economics of structured finance, Journal of Economic Perspectives, vol. 23, no. 1, $3-25$.

D'Arista, W.J. 1994. The evolution of US finance volume II. Restructuring institutions and markets, Routledge, London and New York.

D’Arista, W.J. 2009. Setting an agenda for monetary reform, PERI working paper series no. 190.

Dymski. G. 2010. Why the subprime crisis is different: a Minskyian approach, Cambridge Journal of Economics, vol. 34, no. 2, $239-255$.

Epstein, G. 2005, Introduction: Financialization and the world economy, in Epstein G. (ed.), Financialization and the world economy, Edward Elgar, Northampton.

Eatwell J., Mouakil, T. and Taylor, L. 2008. Liquidity, leverage, and the impact of sub-prime turbulence. Centre for financial analysis and policy, Judge Business School, University of Cambridge.

Gabor, D. and Vestergaard, J. 2016. Towards a theory of shadow money. INET research paper April 2016, url: https://www.ineteconomics.org/uploads/papers/Towards_Theory_Shadow_Money_GV_INET.pdf.

Gorton, G.B. 2010. Slapped by the invisible hand. The panic of 2007, Oxford University Press, New York. 
Gorton, G.B. and Metrick, A. 2010. Regulating the shadow banking system, Brookings Papers on Economic Activity, Fall 2010, 261 - 312.

Gorton, G.B. and Metrick, A. 2012. Securitized banking and the run on repo, Journal of Financial Economics, vol. 104, no. 3, 425 - 451.

Kaldor, N. 1939. Speculation and economic instability, The Review of Economic Studies, vol. 7, no.1, 1-27

Kregel, J. 2009. Background considerations to a regulation of the US financial system: Third time to charm? Or strike three?, Levy Economics Institute of Bard College working paper no. 557.

Kregel, J. 2016. The regulatory future, FESSUD working paper no. 164.

Krippner, G.R. 2005. The financialization of the American economy, Socio-economic Review, vol. 2, no. 2, $173-208$.

Kumhof, M., Rancière, R. and Winant, P. 2015. Inequality, leverage and crises, American Economic Review, vol. 105 , no. $3,1217-1245$.

Lapavitzas, C. and Powell, J. 2013. Financialization varied: a comparative analysis of advanced economies, Cambridge Journal of Regions, Economy and Society, vol. 6, no. 3, 359 - 379.

Lavoie, M. 1984. Credit and money: overdraft economies, and post-Keynesian economics, pp. 63 - 84, in Jarsulic, M. (ed.), Money and macro policy, Springer Science, New York.

Lavoie, M. 2012. Financialization, neo-liberalism, and securitization. Journal of Post Keynesian economics, vol. 35 , no. $2,215-233$.

Lazonick, W. and O’Sullivan, M. 2000. Maximizing shareholder value: a new ideology for corporate governance, Economy and Society, vol. 29, no. 1, 13 - 35 .

Lysandrou, P. 2005. Globalisation as commodification, Cambridge Journal of Economics, vol. 29, no. 5, 769 $-797$.

Mayer, M. 1998. The bankers. The next generation. Truman Talley Books/Plume, New York.

Marx, K. 1981. Capital: Volume 3, Penguin Books, London.

McCulley, P. 2009. The shadow banking system and Hyman Minsky's economic journey, Global Central Focus, Pimco. 
Mehrling. P. 2012. The inherent hierarchy of money, pp. 394-404, in Taylor, L., Rezai, A., Michl, T. (eds.), Social fairness and economics: Economic essays in the spirit of Duncan Foley, Routledge, New York.

Michell, J. 2016. Do shadow banks create money? 'Financialisation' and the monetary circuit, postKeynesian Study Group (PKSG) working papers no. 1605.

Minsky, H.P. 1975. John Maynard Keynes, Columbia University Press, New York

Minsky, H.P. 1986. Stabilizing an unstable economy, McGraw-Hill, New York.

Minsky, H. P. 1988. Schumpeter: finance and evolution, Hyman P. Minsky Archive Paper no. 314. http://digitalcommons.bard.edu/hm_archive/314

Minsky, H.P. 1996. Uncertainty and the institutional structure of capitalist economies. Remarks upon receiving the Veblen-Commons award, Journal of Economic Issues, vol. 30, no. 2, 357 - 368.

Nersisyan, Y., and Dantas, F. 2018. Rethinking liquidity creation: banks, shadow banks and the elasticity of finance, Journal of Post Keynesian Economics, vol. 40, no.3, 279 - 299.

Nersisyan, Y. and Wray, L. R. 2010. The trouble with pensions: Toward an alternative public policy to support retirement, Levy Economics Institute of Bard College Public Policy Brief Archive no. 109.

Nikolaidi, M. 2015. Securitization, wage stagnation and financial fragility: A stock-flow-consistent perspective, Greenwich Papers in Political Economy no. 27.

Olson, P. 2012. Regulation's role in bank changes, FRBNY Economic Policy Review, vol. 18, no. 13, 13 20.

Palley, T.I. 2013. Financialization: The economics of finance capital domination, Palgrave Macmillan, Basingstoke.

Parguez, A. and Seccareccia, M. 2000. The credit theory of money: The monetary theory approach, pp. 101 - 123, in Smithin, J. (ed.), What is money?, Routledge, London and New York.

Pozsar, Z., Ashcraft, A., Adrian, T., and Boesky, H. 2013. Shadow banking, FRBNY Economic Policy Review, vol. 19, no. 2, 1 - 16 .

Rochon, L.P., 1999 Credit, money and production: An alternative post-Keynesian approach, Edward Elgar, Northampton. 
Rochon, L.P. and Rossi, S. 2007. Central banking and post-Keynesian economics, Review of Political Economy, vol. 19, no. 4, $539-554$.

Singh, M. 2011. Velocity of pledged collateral: analysis and implications, IMF working papers no. $11 / 256$.

Taylor J.B. 2009. Getting Off Track: How Government Actions and Interventions Caused, Prolonged, and Worsened the Financial Crisis, Hoover Press, Stanford.

Tobin, J. 1963. Commercial banks as creators of "money", Cowles Foundation Discussion Paper no. 159.

Toporowski, J. 2000. The end of finance, Routledge, USA.

Tymoigne, E. 2009. Securitization, deregulation, economic stability, and financial crisis, part I: The evolution of securitization, Levy Economics Institute working paper no. 573.

Van der Zwan, N. 2014. Making sense of financialization, Socio-Economic Review, vol. 12, no. 1, 99 - 129.

Zalewski, D.A. \& Whalen, C.J., 2010. Financialization and income inequality: A post-Keynesian institutionalist analysis, Journal of Economic Issues, vol. 44, no. 3, 757-777. 


\section{Footnotes}

${ }^{1}$ Palley (2013, p.26) stresses that "in 1979 the income of the top 5 per cent of families was 11.4 times the income of the bottom 20 per cent of families. By 2006 this ratio had risen to 21.5 times”.

2 Adrian and Ashcraft (2012:31) explicitly refer to shadow credit intermediation.

3 More specifically, Rochon and Rossi (2007) and Gabor and Vestergaard (2016) both stress that the stability characterizing banks' money-centered payment systems (and making banks' deposits perceived as highly safe means of payments) relies upon the "requirement of using central bank money to set interbank debts [which in turn] guarantees internal convertibility between commercial and central bank monies" (Rochon and Rossi, 2007: 547).

${ }^{4}$ We simplified the approach of the FED, as the FED identifies 27 sectors within the financial system. For instance, in Figure 1 we merged Pension Funds, Mutual Funds, Closed-end funds, and Exchange-traded funds into a single sector Investment Funds.

${ }^{5}$ MMMFs and Mutual Funds appear as additional relevant source of funds for investment banks into repo contracts.

${ }^{6}$ A further simplification of the social accounting reported in the tables is the inclusion of MBS among liabilities. Passing through securities is not an obligation of the originator.

${ }^{7}$ D'Arista (1994) early stressed in a quote of the previous SEC Chairman John Shad how “for investors securitised credit was seen as a boon (italics is by the authors) securitization permits institutions and individual investors to obtain returns close to those previously only available to prime lenders, as well as diversification, professional selection, liquidity, and in some cases the benefit of government guarantees or private insurance" (D'Arista, 1994: 273).

8 In its original Marxian acceptation, the commodification of capital was referred to the stock of wealth lent by the capitalists instead of being used for industrial production. Combining the two concepts, we could say that through securitization financial relations are commodified and transformed into a claim on money to be purchased by those willing to commodify the capital they own in money form.

${ }^{9}$ Following Palley (2013), a significant part of the increase in overall debt is precisely due to the astonishing rise of the intrafinancial sector debt. In the same vein, D’Arista (2009) notes in a quote of the previous SEC Chairman John Shad, that from 1997 to 2007 "the most dramatic development was the jump in the debt of the financial sector to 113.8 percent of GDP from 63.8 percent only a decade earlier, [a fact that] signalled rising speculation and reflected the new funding strategy adopted by a profoundly changed financial system” (D’Arista, 2009: 8).

${ }^{10}$ Mayer (1998) describes the weakness of banks' screening and monitoring of borrowers' creditworthiness once loans are securitized (small business loans in Mayer's example) and put out of the balance sheet: "Instead of taking the time to learn about the small entrepreneur and his enterprise, banks are now attempting to "score" small-business loans [...] on a standardized form with places for machine-readable pencil marks [...]. Clerks can do the work of filling out the form for 
scored lending in a "branch" that occupies four hundred square feet of a supermarket - or over the telephone. At Texas Commerce Banks, such loans can be ordered by telephone” (Mayer, 1998:222).

11 Argitis and Pitelis (2001) analyze how historically high interest rates as induced by restrictive anti-inflation monetary policies in the US and the UK since the late 1970s may have created a rentier-friendly environment by changing income distribution in favor of financial capital with respect to industrial capital and wage income.

${ }^{12}$ Following Minsky (1986), such a conceptual distinction between banks' money and MMMFs' share is obviously subject to changes according to the evolutions of those institutions and the way they interact with other players in the financial system, namely monetary institutions. Indeed, the difference between bank money and MMMFs' shares may progressively blur away as soon as MMMFs will be allowed to get access to the lender-of-last-resort activity of central banks and given that "some MMMFs accounts are "checkable" (i.e. customers can write checks on their account similar to bank checkable deposit accounts)" (Nersisyan and Dantas, 2018: 290).

${ }^{13}$ In this sense, we share Kregel's concern (see Kregel, 2009) about the manufacturing of complex financial products as a fundamental source of financial instability. Our policy proposal aims at removing incentives and mechanisms that may encourage the production of opaque "financial goods" with the sole purpose of generating new profitable arbitrage opportunities for a wide range of financial institutions. 